\title{
INDONESIA ENVIRONMENTAL DIPLOMACY IN PRESIDENT JOKO WIDODO'S ERA (2014-2019) OF THE ISSUE REJECTION INDONESIA'S CPO BY EUROPEAN UNION
}

\author{
Theresia Kurniaty \\ International Relations, Pelita Harapan University, Jakarta \\ siahaanthere@gmail.com
}

\begin{abstract}
Environmental diplomacy is one of discipline in International Relations, which combines ecological problems involving other countries and uses negotiation as solutions. The policy of the European Commission through Renewable Energy Directive II for Indonesia put palm oil discriminated among another vegetable oil. This research found that in Joko Widodo's era, Indonesia has carried out its role as an international agent with some policies related to managing sustainable palm oil. Indonesia also uses bilateral, multilateral, and global approaches, and even the involvement of international organizations as a peaceful way resolving palm oil disputes for the target of Sustainable Development Goals' through palm oil.
\end{abstract}

Keywords: Environmental Diplomacy, Palm Oil, Renewable Energy Directive II, European Union, Export, Rejection

DOI: 10.33541/sp.v21i1.1585

Sociae Polites : Majalah Ilmiah Sosial Politik

Faculty of Social and Political Science, Universitas Kristen Indonesia

ISSN 1410-3745 print/ ISSN 2620-4975 online

Volume 21, Number 1 (January - June 2020)

Pages 74-95 


\section{Introduction}

Crude Palm Oil (CPO) has become one of the strategic commodities in Indonesia, most of which include natural resources sold to the international market or export commodity. The Indonesian palm oil industry is developing rapidly in the past fifteen years as a noted database from PASPI (Palm Oil Agribusiness Strategic Policy Institute). In 2017, Badan Pusat Statistik recorded the export value of Indonesian Palm Oil products amount to USD 23 billion and exceeded Indonesia's oil and gas exports amount to USD 15 billion (PASPI, 2017:37). During the year, CPO Production amount to 37.8 million tons, and the current area of palm oil plantations reached 14.03 million hectares. With this figure, Indonesia is one of the largest palm oil producers in the world, together with Malaysia, which currently controls the world market share of palm oil of around 85 percent of CPO Production.

The trade export of palm oil improves the welfare of palm oil farmers in Indonesia. Starting from 2011 to only 3.7 million hectares until 2015, the total area of land owned by farmers amounted to 4.7 million hectares. According to data taken by PASPI, it estimated that by 2020 the city of farmers' plantations could be expected to reach 50 percent (PASPI, 2017:66). From this data, palm oil contributes to the economic life of not only the private sector but also the smallholders.

In the middle of the struggle, when Indonesia is trying to develop the economy and make the improvements to the environmental sector, the European Union issued the Renewable Energy Directive (RED) in 2009 and continues to update until now. RED is a development of the European Union's journey in carrying out its commitment to supporting sustainable development. This guideline is continually updated with the appearance of RED I and replaced again by RED II. The most recent, in March 2019, the European Union issues a Press Release, which mentions the EU's commitment to using bioenergy towards energy and climate targets in 2020 and 2030. This Press Release is a framework of EU Policy in following up on the approval of the European Parliament and EU countries in June 2018 through RED II.

One of the impacts of the RED is the prohibition on using palm oil as a raw material for biofuel in Europe in 2030, including crude palm oil from Indonesia. This prohibition is going to be a problem for Indonesia. Palm oil is a commodity that gives an enormous advantage for economic growth. The main reason, according to the EU, is Indonesia's palm oil has caused the damaging of the environment. It marked by illegal burning of land, which causes air pollution and haze disaster, the use of pesticides, injustice for small farmers and indigenous peoples, even threats to the forest ecosystem such as Orangutan.

In President Jokowi's era, the government itself is dealing with this environmental issue, and it will not let Indonesia's palm oil sink, which can disrupt the stability of Indonesia's trade. Hence, diplomacy and negotiation are very needed in terms of RED Policy. Of course, it will not easy if our delegation had not carefully prepared it in making resolutions related to environmental issues.

This research focuses on Indonesia's environmental diplomacy during President Jokowi's era as a solution to the rejection of the EU. Environmental diplomacy was chosen because Indonesia is not only concerned with economic growth but also the environment and sustainable development. The state must consider domestic interests and external pressure in resolving global environmental issues. The extent to which environmental diplomacy plays an essential role in addressing this problem is not only to 
save Indonesia's palm oil commodities but also to Indonesia's efforts to continues implementing the applicable regulations in the international regime. This research will look at diplomacy conducted by Indonesia and the instruments used by Indonesia through media, diplomatic presentations, meetings between two countries, and also cooperation between countries.

\section{Environmental Diplomacy in International Relation}

In terms of definition, the term 'environmental diplomacy' is still new and debated by researchers (Saleem H. Ali and Vladich, 2016:601). This definition is debatable when there are two points of view in this study. According to the International Relations scheme, the definition framework surrounds environmental governance negotiations between the two countries. As for interdisciplinary researchers on environmental education, this term has a broader meaning around negotiations related to conflict resolution over natural resources and the use of environmental instruments in resolving disputes and building peace (Saleem H. Ali and Vladich, 2016:601).

If we elaborate on each science in a definition theory, it will be very different. However, in International Relations, some problems must be resolved across national borders, for example, the case of haze in Southeast Asia. Haze arises from the burning forests in Indonesia. Forest-fires and haze pollution is human-made disasters in Southeast Asia (Verdinand and Yanyan, 2018:118). This disaster also affected neighboring countries, such as Singapore, Malaysia, and Brunei, and it endangered human health and disrupted public activities for several days. In other words, actions that are caused within the country can become a global problem when it involves losses of their countries. International relation answers questions between environmental issues and the country's foreign policy. These studies will answer the question of how the role of power and national interests, institutions, and international norms, including international cooperation, is unique in one country and another in resolving environmental issues (Kate O'Neill, 2009:2). All these studies help researchers to understand those international relations as a multidisciplinary science, so with the science of international relations, we can resolve environmental problems. This study also helps us that the state has a role as a global actor, and it must consider national interests. At the same time, resolve external pressures, especially those related to the environment.

In term of environmental diplomacy by Simone Borg in 1994 made a reasonably simple definition which is quoted below :

"Environmental diplomacy can be defined as the skill in handling environmental issues, whose implications are international in scope."

( Pramudianto, 2008:20)

The definition of Borg above shows that the expertise success of diplomacy in international relations, especially to know and understand environmental issues, will have a considerable impact. Environmental diplomacy in the study of International Relations is the best method for international or ordinary discourse as well as the art of managing international relations, primarily through negotiations, on issues related to the environment (Balakhrisna, 2015:4). 
Global environmental problems expose significant diplomatic and legal challenges to the international community. The nature of this problem requires a degree of international cooperation in terms of scientific research and the harmonization of regulations achieved through the process of negotiating environmental issues (Pamela S. Chasek, 2001:4). The same thing was written by the American Institute for Contemporary German Studies that environmental diplomacy has contributed to improving the environment where the benefits of environmental diplomacy itself are not only be felt by one country but also by other countries. According to them, environmental diplomacy can be defined as a combination of tools and approaches used to help disputants in creating opportunities for cooperation, building trust, and also conflict resolution related to environmental issues and shared natural resources. Environmental diplomacy turned out to have been debate from the past, and now it becomes new because there have been many researchers who study environmental diplomacy in international relations.

Environmental problems in Indonesia have occurred since late 1997 and early 1998. The fire spread rapidly through bushes, forests, and peat, swamps in eastern Indonesia, destroying nearly 10 million hectares. These fire resulted in the thick fog around Southeast Asia, affecting public health and damaging the tourist trade. The crossborder consequences of fires change what was originally a national environmental problem to evolve into one of the regional and global dimensions.

"The Indonesian fires were transformed from a national problem into an issue of regional and global significance. Yet despite serious public concern and pressure for action, the reactions of officials at all three levels seemed hesitant, slow, and largely effective". (Springer, 2002: 60)

Impacts from the fires focus international attention on developing practical steps to prevent or increase mitigating the same situation over and over. The nature of global response also raises important questions about the development of law and protection of the international environment, both in practice and in principle.

Some literature studies also discuss environmental diplomacy as one of Indonesia's ways to solve environmental problems due to increasing public concern about environmental issues. The emergence of new norms such as sustainable development, climate responsibility of environmental ethics is part of a general discussion between the community, companies, and countries ( Sinaga, 2018 ). Indonesia is still one of the world's most significant contributors to greenhouse gas emissions related to forest fires in peatland. In the nationally determined contribution document submitted to the UNFCCC, the Indonesian government aims to reduce its emissions by $26 \%$ in 2020 and $41 \%$ with international support for ordinary business. One of the main strategies to achieve this ambitious goal is through a drastic reduction of forest fires on peatlands. Forest fires on peatlands have caused deadly damage to Indonesia and neighboring countries ( Sinaga, 2018).

The next literature review is written by Shofwan Al Banna Choiruzzad entitled "Save Palm Oil, Save The Nation: Palm Oil Companies and the Shaping of Indonesia's National Interest," which contributed to this research related to palm oil which is of national interest and a topic in Indonesian diplomacy. Palm oil is a significant problem with Indonesia's diplomacy, where President Joko Widodo considers this to be a severe problem. President Joko Widodo, in 2014 continued the inclusion of palm oil as a priority 
in Indonesian diplomacy. During this first meeting with foreign officials, including US President Barrack Obama and European Council President Herman van Rompuy in November 2014, President Joko Widodo asked them to stop acts of discrimination against Indonesian Palm Oil ( Bertemu Presiden Uni Eropa, 2014). Environmental problems caused by the planting of palm oil have made palm oil become a national interest that must fight for Indonesia's foreign policy. Since the beginning of 2010, palm oil has been included as one of the priorities in Indonesia's foreign policy. Indonesia even formed a CPOPC to promote palm oil exports to alleged "black campaign" from other vegetable oil-producing countries.

Al Banna wants to show that palm oil has changed from being just the most significant commodity in Indonesia but has become Indonesia's national interest. The results of this journal study conclude that the case of the inclusion of palm oil in Indonesia's foreign relations priorities shows as the result of competition among other subnational benefits is true (Al Banna, 2019). The journal summarizes the theoretical arguments for how a commodity in a developing country can compete and turn into the country's national interests and even become one of its foreign policy priorities. This argument can be strengthened if we compare it with the theory of two-level games. Indonesia must stand on two-sides, namely national interests related to economic development and social life; on the other hand, Indonesia, as an international actor, must meet the requirements of sustainable development in the international regime.

Through the literature review that has been described, several journals discuss how palm oil becomes a strategic issue to be addressed domestically and even internationally. Indonesia's policies are always monitored both by other countries and also by environmental activists. Indonesia has made efforts could maintain palm oil as one of the economic backers of developing countries and also be able to maintain its position at the global level. Although there are still many shortcomings that occur on the ground, Indonesia has tried to keep up with European demands regarding oil palm cultivation. Indonesia needs to use environmental diplomacy as a weapon to convince the international community that Indonesian palm oil is in line with global goals, namely sustainable development.

\section{Neoliberalism and two-level games theory}

The keyword of neoliberalism is the concept of an international regime as the following quotation is written :

"States have also created informal institutional arrangements, or international regime, which consists of 'sets of implicit or explicit principles, norms, rules, and decision-making procedures around which actors' expectations converge in a given area of international relations"' (Krasner 1983: 2)

In addition to the concept of the international regime, neoliberalism also prioritizes cooperation in achieving the goals of international relations between countries to cause interdependence among nations. In this case, the state is still crucial, but it must facilitate the functions of international organizations. 
International regimes, international markets, and institutions will serve as a theoretical framework for researchers in discussing environmental diplomacy related to the rejection of Indonesian palm oil by the European Union. The increase in CPO exports will be an achievement of Indonesian's international trade because it will provide state foreign exchange. The planned restriction of the European Union will hamper Indonesia's export markets. On the other hand, the international regimes on the environment have also become a global issue, where the role of institutions to achieve a political economy perspective on the subject of rejection of Indonesian palm oil.

The concept of neoliberalism theory is not enough because it will be reviewed by Indonesian diplomacy to defend Indonesia's national interests, namely Indonesia's CPO exports. Indonesia, in this case, must stand at two sides. First, Indonesia must follow the international regime, but on the other hand, Indonesia must defend the interests of the people's welfare through the export trade in palm oil. The theory of two-level games makes a theoretical framework facing Indonesia today.

Robert D. Putnam introduces the linkage of domestic politics and international politics into logic called two-level logic. The politics of many international negotiations can be considered as two-level games (Putnam, 1998). At the national level, domestic groups pursue their interests by pressuring the government to adopt political policies in their favor and build coalitions to gain strength between groups. At the international level, national governments maximize their ability to meet domestic desires, while at the same time minimizing the adverse consequences of international development. Both of these games are difficult to avoid as long as the country is interdependent. This two-level game theory that was put forward by Putnam is the art of diplomacy in domestic politics.

Indonesia's environmental diplomacy must face this dilemma. On the one hand, economic diplomacy has a target of achieving foreign investment. Still, on the other hand, environmental diplomacy must deal with Western countries with rejecting the products of developing countries. Indonesia's environmental diplomacy must convince Western countries that Indonesian products do not endanger Indonesia's ecosystems, biodiversity, and forest integrity.

\section{Sustainable environment}

A sustainable environment is increasingly echoed internationally until now, and one of them is the European Union. This concept of sustainable environment influences other countries in taking their domestic policies. Andrew Hurrell and Benedict Kingsbury, in their book The International Politic of The Environment, 1992, described the response of the countries facing challenges of environmental problems. It occurs by forming practical international cooperation and agreements that can be implemented by looking at the actors, interests of related parties, and institutions involved.

"The objective is not to provide detailed scientific treatment of the nature of the major environmental challenges facing the world, but rather to explore the international political forces that work to complicate the negotiation and implementation of rational environmental policies between states (Hurrell, 1992:1)

In discussing international politics on the environment, Hurrell and Kingsbury discuss processes of negotiations between countries on the environment, with rules and 
regimes established to facilitate environmental cooperation, including with international institutions that have or need to be created to implement those rules.

\section{Example of sustainability requirements as defined by the EU Directive 2015/1513 amending the Renewable Energy Directive 2009/28/EC and the Fuel Quality Directive 98/70/EC}

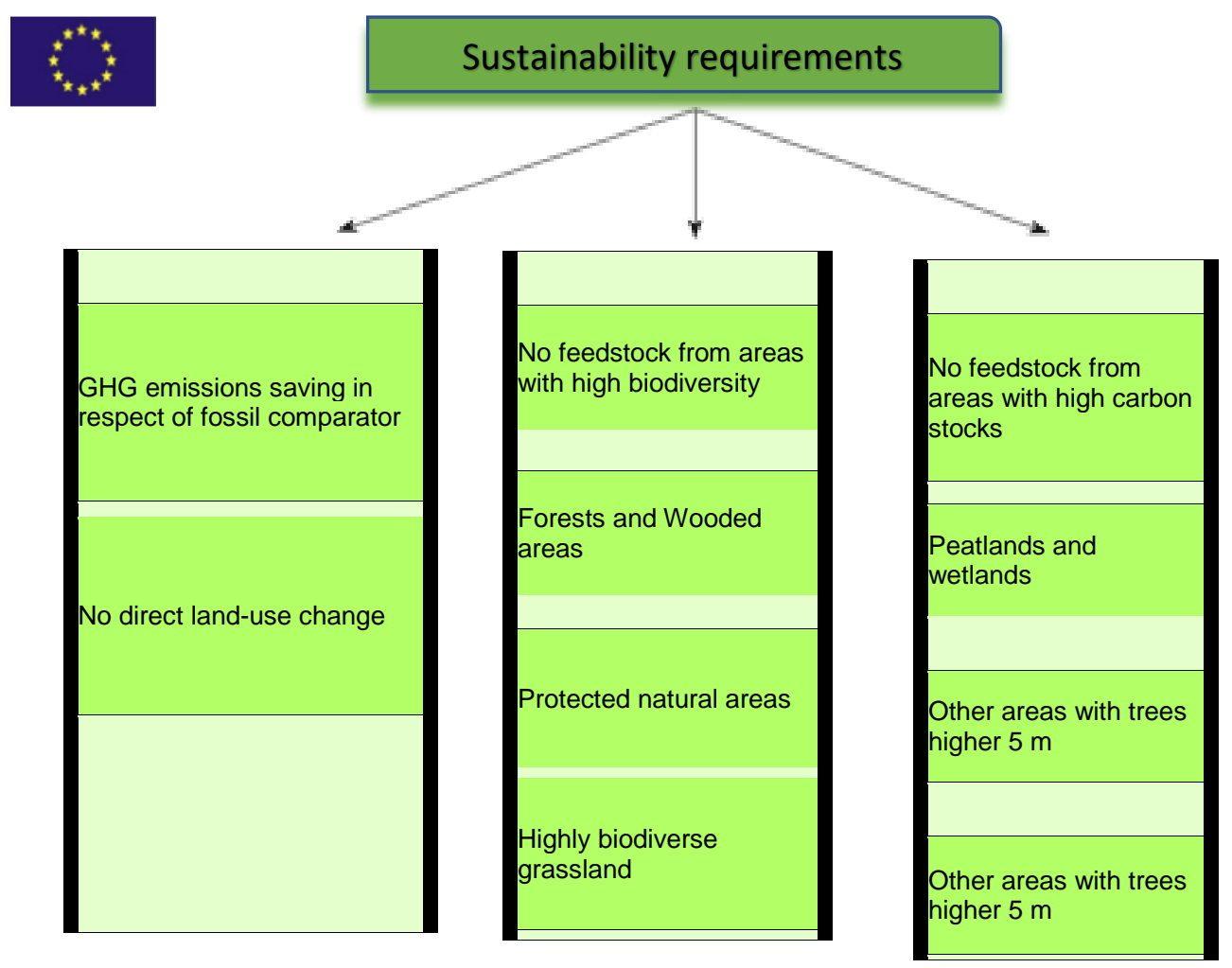

This sustainability requirement becomes the European Union standard regarding deforestation. If some actors or stakeholders deliberately do this, then it can be said to have done deforestation. Besides, the European Commission also applies the standard setting for sustainable palm oil. The Renewable Energy Directive 2009/28/EC, which was subsequently revised to the 2015/1513 Directive, is a regulation that sets the standard for the use of transportation fuels from biofuels by $10 \%$. As a result, this directive encourages the use of alternative raw materials for biofuel production while limiting biofuel vegetable oils on the EU market. Indonesia must also comply with the international regime on the concept of a sustainable environment, according to the European Union. Here it shows that there is a tug of war between national interests and also the interests of international regimes following the theories of Hurrell and Kingsbury.

\section{Indonesia's CPO Exports to European Union}

Before we talk about environmental diplomacy, we have to know first why Indonesia's environmental diplomacy is needed to defend Indonesia's palm oil internationally. One of the reasons is because of economic interests. Although Indonesian palm oil has been protested by many parties, in terms of trades, palm oil can still survive 
in the international market. Therefore, Indonesia strives actively for the existence of this commodity through Indonesia's environmental diplomacy.

Patterns of Vegetable Oil Consumption in the EU 1996-2016

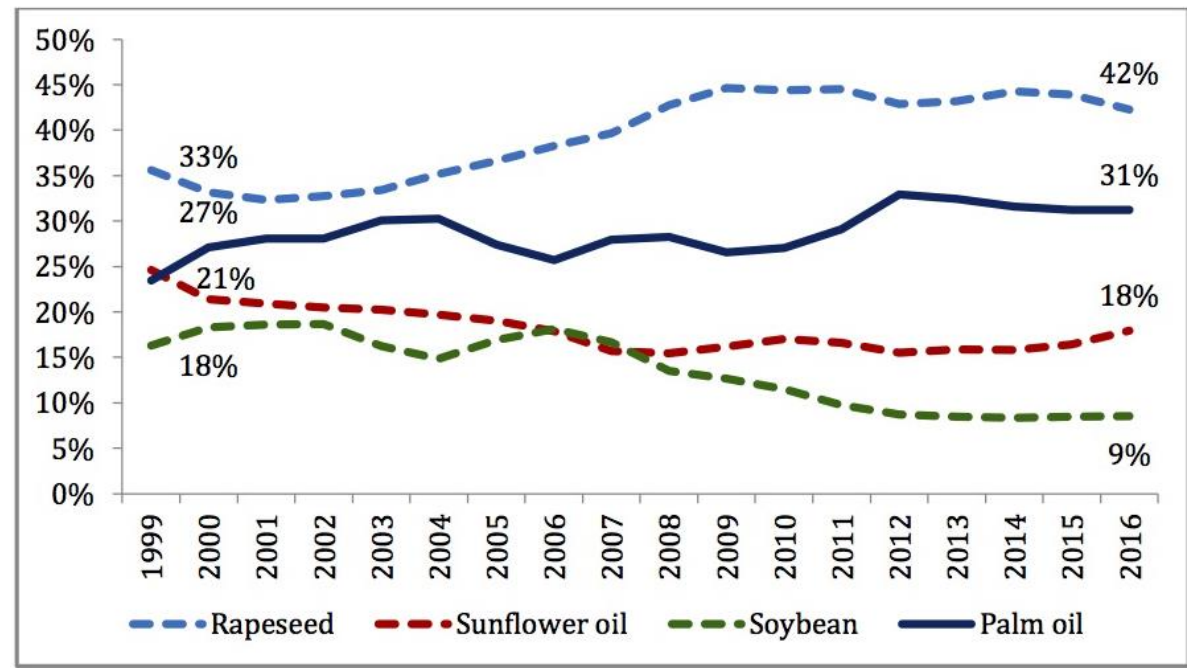

Source: United States Department of Agriculture

The EU demand for CPO is reflected in this table. Palm oil commodities will always be associated with the consumption of other vegetable oils in the European Union, or which is rapeseed oil (RSO). The data shows that one-third of the EU vegetable consumption in 2000 was rapeseed oil, and in the second position was palm oil (CPO) with a percentage of $27 \%$. The third position was soybean oil (soybean), and the last, which ranks lowest, is sunflower oil (SFO) with a share of 18\% (PASPI, 2018).

When we are talking about the ability of domestic Europeans to meet vegetable oils, the fact shows that the average growth of local production of vegetable oil in the EU is 2.8 percent per year. In contrast, the growth rate of consumption is far higher, at 4.8 percent. This situation causes a more significant demand for production, so there is no other choice in addition to import policies.

In 2016, total CPO imports reached 7.2 million tons, followed by SFO 1.3 million tons, RSO 300 thousand tons, and SBO 250 thousand tons. These data give us a visible message that $\mathrm{CPO}$ has a very high contribution to meeting EU vegetable consumption. The CPO contribution reaches 80 percent of the total vegetable imports, while the SFO is 14 percent, SBO 3 percent, and RSO 3 percent (PASPI, 2018). During the 2011-2016 period, Indonesia's average CPO exports to the European Union were around 60 percent per year and the rest by Malaysia. This data gives a powerful message that Indonesia has a huge role in meeting EU vegetable oil consumption. 


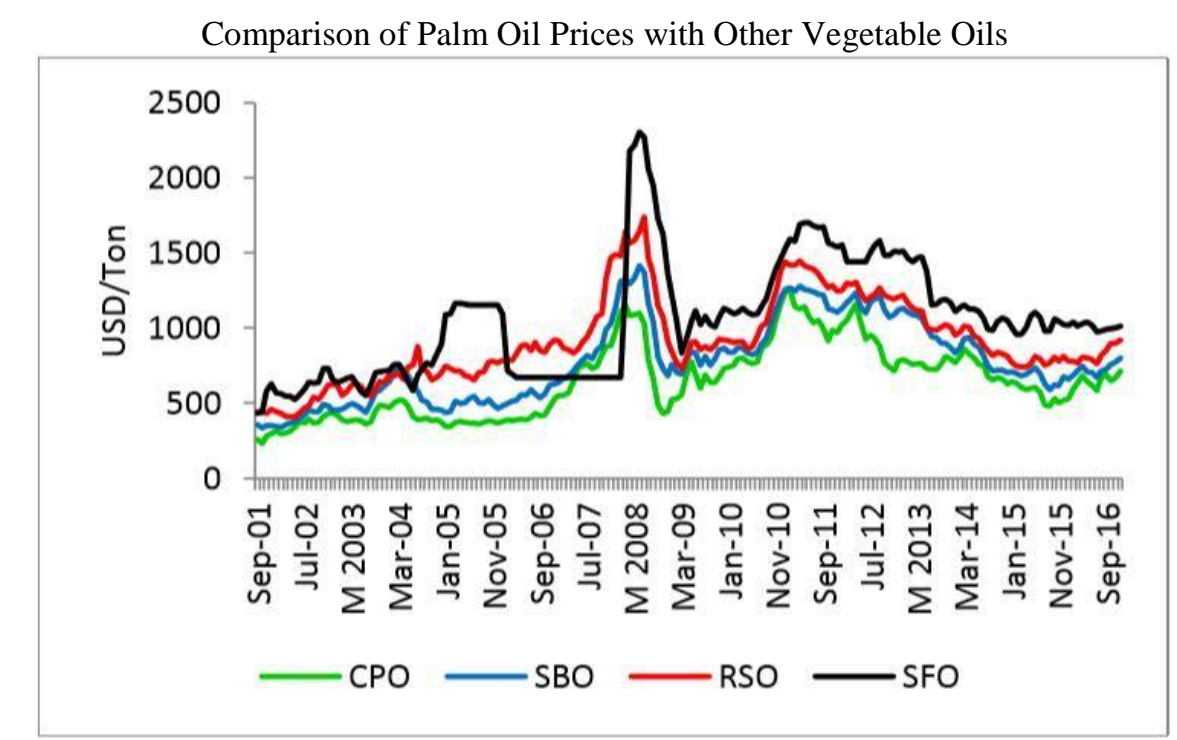

Source: World Bank, 2017 (https://gapki.id/news/4175/mitos-2-07-minyak-sawit-merugikannegara-negara-berpendapatan-rendah)

The comparison of the prices of $\mathrm{CPO}$ and other vegetable oils has also become one of the factors Indonesia's CPO trends increased. If we analyzed further, by comparing the cost of CPO with soybean oil, the price of rapeseed oil, and the price of sunflower oil, it appears that the CPO price is consistently lower compared to other three vegetable oil sources. The position of CPO in the EU can be seen as substitute goods, and CPO has a relatively lower price so that CPO flows swiftly to the European Union. CPO price ratio in 2015, namely the cost to buy 2 tons of RSO, can get 3 tons of CPO. The European Union benefits from 1 ton, with the same amount.

Empirically, the data shows that Indonesia's CPO exports to the European Union have a positive trend or have increased in 2017. The data indicate that the palm oil resolution issued by the European Parliament in April 2017 was not easily implemented to curb the pace of CPO exports to the European Union.

Analysis of positive trends in CPO sales abroad, by the results of the author's interview with the Executive Director of the Indonesian Palm Oil Entrepreneurs Association (GAPKI), Mr. Mukti Soerdjono. According to him, despite the threat of rejection imports of Indonesian palm oil by the European Union, the impact is not very significant on the trade balance. The demand for imports is still quite high from the EU's countries. He also said that it was tough for the European Union not to use palm oil as a raw material for food. "Palm oil from Indonesia is cheaper than other vegetable oil so that the trade balance is still positive," Mr. Mukti Soerdjono explained. Palm oil prices declined precisely not because of the discourse of rejection from the European Union, but because of the American and Chinese trade wars that could cause supply to exceed demand. Plus, according to him, even if indeed the discourse happened, Indonesia has prepared a plan that is increasing domestic demand policies on the use of transportation fuel derived from biofuels B20 and B30. This policy is expected to help palm oil producers if the European Union imposes a rejection of CPO from Indonesia.

\section{Indonesia's environmental diplomacy during Joko Widodo's leadership}


Diplomacy is a state instrument in implementing its foreign policy to achieve national interests. Palm oil is essential for Indonesia's national interests in terms of economic, socio-economic, employment, regional development, and poverty alleviation. When conflicts occur between countries and relate to environmental and natural resource issues, then environmental diplomacy is needed as a solution to the conflict. Based on neoliberalism theory and two-level games theory, the state must meet existing international regimes and also must meet the country's growth needs. At the beginning of this analysis, researchers will describe President Joko Widodo's two domestic policies, which will be used as contents of Indonesia's environmental diplomacy to the global level. These two policies are a form of Indonesia's compliance in realizing living sustainable environment diplomacy to the European Union. After knowing the domestic policies, the types of Indonesian environmental diplomacy during President Joko Widodo's administration will be elaborated on the rejection of Indonesia's CPO by the European Union.

\section{Establishment of the Indonesian Peat Restoration Agency (BRG)}

The rejection of palm oil by the European Union is the other side of the impact of environmental problems in Indonesia. Surprisingly, Indonesia is now one of the 20 largest economies in the world and the largest in Southeast Asia. Massive economic modernization has led to the rise of millions of new middle classes with better access to education and health services. However, Indonesia also faces urgent problems related to the environment, land use, and the forestry sector (Verdinand, 2018). The losses incurred are also for each stakeholder. Here we need the right policies from the government and sustainable development at the regional and global levels.

BRG has become very important for Indonesia's environmental diplomacy because peatland restoration must deal with resistance from the palm oil, rubber, and wood-based industries. As discussed in the previous sub-chapter, this industry is an essential contributor to government revenue and community welfare.

BRG is also a commitment of President Joko Widodo in maintaining his political promises to global organizations and domestic constituents. President Joko Widodo delivered a speech at the Conference of Parties 21 on November 30th' 2015 stating Indonesia's commitment to restore two million peatlands by 2020 . The President also said that Indonesia is committed to reducing emissions by $29 \%$ under business as usual by 2030 and $41 \%$ with international assistance (UNFCCC, 2015). In the realm of domestic politics, the President has Nawa Cita - nine principles, including implementation to empower strategic internal resources such as forests (KLHK, 2015).

According to the Head of BRG, Nazir Foead, for the first time in Indonesian history, the Indonesian government was prepared to sacrifice short-term economic interests for long term environmental protection (Obsatar, 2018) that the contradiction between the state and the environment is increasingly disappearing. Foead stressed that the palm oil industry needs to be limited by using government regulations and international community intervention. Furthermore, according to him during the Jokowi's administration, there was a defense from the government against the constraints of palm oil because of Indonesia's national and international responsibilities in protecting peatland. 
It is not only about forest conservation but also Indonesia's readiness to oppose the European Union regarding forest management. The European Union is determined to impose palm oil obligations due to poor management of Indonesia's forests. Instead of fear punishment, the Indonesian government challenges the European Union database. In a visit to Brussels, read supporting significant data logging, land degradation, and forest fires. Indonesia Foreign Minister, Retno Marsudi, also claimed there were key reforms in environmental management such as the formation of Indonesia Sustainable Palm Oil (ISPO). This private mechanism prevents deforestation and land degradation (detikcom, 2017).

The Peat Restoration Agency is a piece of evidence that Indonesia, under the leadership of President Joko Widodo has made reforms in addressing the problem of deforestation in Indonesia. BRG is a tool for the Indonesian delegation to conduct environmental diplomacy in defense of Indonesia's national interests, namely the Indonesian palm oil commodity.

\section{President Instruction Regarding the Indonesian Palm Oil Moratorium}

The second policy after the Establishment of BRG, which influenced Indonesia's environmental diplomacy, was the Presidential Instruction on the Indonesian Palm Moratorium. The moratorium has an impact on licensing the opening of palm oil land in Indonesia so that indirectly impacts on Indonesia's environmental conditions. In 2018, President Joko Widodo issued Presidential Instruction (Inpres) No.8 of 2018 concerning the Postponement and Evaluation of Palm Oil Plantation Licensing and Increased Productivity of Palm Oil Plantation. The purpose of Presidential Instruction No. 8 /2018 is written as follows :

"In the context of improving the management of sustainable palm oil plantations, providing legal certainty, protecting the environment, including reducing greenhouse gas emissions, as well as enhancing the performance of palm oil development and increasing the productivity of palm oil plantations,...."

President Joko Widodo's instructions related to palm oil is a form of President's commitment to creating sustainable environmental development. Regulatory guidance is proof that Indonesia complies with international regime standards associated with a sustainable environment. Indonesia has shown its commitment to improving governance in sustainable palm oil plantations. After the formation of the Peat Restoration Agency in 2016, Joko Widodo issued this instruction two years later as a continuation of the government to improve governance of sustainable palm oil plantations, provide legal certainty, and preserve the environment. The following are institutional tasks based on the palm oil moratorium rules.

According to the representative from Ministry of Environment and Forestry (KLHK) from the Seminar "What Palm Oil Moratorium News" held by the KLHK itself, governance of palm oil plantations is crucial because so far, there are many overlapping licenses. Also, the main thing is to improve environmental conditions to improve the climate. The implementation of the Instruksi Presiden will contribute to the reduction of greenhouse gases. 
On the other side of the Ministry of Foreign Affairs, Mr. Anwar Luqman Hakim said that one of the palm moratorium policies became direct support from the President in resolving the issue of Indonesian palm oil in the European Union. It is Indonesia's commitment as an actor in the International regime, and the Ministry of Foreign Affairs continues to manage its diplomatic strategy to the European Union.

Although it has only been running for one year, the oil moratorium has contributed to the improvement of sustainable palm governance. One of the challenges faced is spatial data to deal with spatial planning and overlapping. The Ministry of Environment and Forestry itself has reconciled the map of national oil cover so that the government has accurate and centralized data on Indonesia's palm oil areas. Besides, The Ministry of Environment and Forestry has postponed licenses and patterns of settlement of palm oil plantations inside forests.

After the elaboration of domestic policies from President Joko Widodo - which will later become the content of Indonesian environmental diplomacy - the government's strategy in negotiating to the international level is an essential key to the success of Indonesia's environmental diplomacy. The government's policy of conducting these negotiations is none other than fighting for palm oil as a strategic Indonesia commodity. One way the government conduct diplomacy is to collaborate with other countries as a form of power in the international regime. The cooperation is a form of environmental diplomacy raging from multilateral forums, regional to the global level. As explained in the theoretical framework, this research uses the theory of neoliberalism, in which the state uses international cooperation as an effort to resolve conflicts. The following will explain some forms of cooperation between Indonesia and other countries.

\section{Bilateral Cooperation: CPOPC (Council of Palm Oil Producing Countries)}

Indonesia initiated a forum to fight for the interests of palm oil together with several palm-producing countries that experienced the same complaints by forming a Charter for the Establishment of the Council of Palm Oil Producing Countries (CPOPC) on November 21st, 2015 (liputan 6.com, 2015). CPOPC is a form of cooperation formed by the two largest palm oil-producing countries, namely Indonesia and Malaysia. CPOPC as Indonesia's strategy by cooperating with Malaysia in facing pressure from palm oil importers, one of which is the European Union. The CPOPC signing ceremony was witnessed by Indonesian President Joko Widodo and Malaysia's Prime Minister, the Honorable Dato' Sri Mohd bin Tun Abdul Razak.

This cooperation was initially felt to be unique because it only consists of two countries. Malaysia itself is the second-largest palm oil producer after Indonesia. Malaysian palm oil industry has a significant impact on the national economy, especially the agricultural sector, and is the $4^{\text {th }}$ most significant contributor to the national economy (Alam and Begum, 2015). In 2017, Malaysia's national income in palm oil reached 82 million. The palm oil industry in Malaysia is concentrated in the workplace, where the growth and production of palm oil employ more than half a million people in Malaysia. A total of 17.73 million tons of palm oil and 2.13 tons of palm kernel oil have been produced from around 4.49 million hectares of land, and approximately $40 \%$ of oil palm cultivation is owned by 640.000 smallholders (cpopc.org). 
For this reason of national importance, Malaysia co-founded CPOPC intending to strengthen palm oil cooperation at the international level. Rizal Ramli, as the Coordinating Minister for Maritime Affairs and Resources at the time, said that this international organization aims to improve the competitiveness of the palm oil strategic industry in the world and, at the same time to improve the practice of nature conservation. Also, the most crucial goal is to raise the welfare of smallholders (liputan 6.com, 2015).

CPOPC bilateral cooperation was established to encourage, develop, and to enhance collaboration in the palm oil industry among its member countries. The CPOPC organization is expected to improve the communication of the palm oil industry among the palm oil cultivation countries, encourage cooperation and investment in building a sustainable and environmentally-friendly palm oil industry zone. It includes the green economy zone, pays attention to barriers to the trade in palm oil, and carry out activities and other functions needed for the benefit of the palm oil industry (liputan 6.com, 2015).

Since it founded in 2015, CPOPC has been running for four years and has held a series of conferences to strengthen investment cooperation between countries of the world palm producers. For example, on October 22nd, 2019, the CPOPC held the " 1 st Palm Oil Supply and Demand Outlook Conference (POSDOC)" in Selangor, Malaysia. The purpose of this conference is to provide a strategic platform for the interaction of in-depth deliberations on three main aspects related to the palm oil industry, namely production supply, market demand, and price design (CPOPC.org, 2019). Besides, the CPOPC also held "The $2^{\text {nd }}$ Ministerial Meeting of Palm Oil Producing Countries" 17-18 November 2019 in Kuala Lumpur, Malaysia. Nine major palm oil-producing countries meet to discuss some critical issues in the palm oil industry and strengthen collaboration between countries. The outcome of this meeting recommends calling for unity among palm oil-producing countries in combating discriminatory measures against palm oil through aggressive joint campaigns. (CPOPC, 2019).

\section{Multilateral Cooperation Level Through WTO}

One of the steps of environmental diplomacy is to take this problem to the global level through the World Trade Organization (WTO). According to Mr. Dindin Wahyudin as Head of the BPPK Multilateral Policy Assessment and Development Center of the Ministry of Foreign Affairs of the Republic of Indonesia in the seminar "Indonesian Palm Oil Diplomacy" said that the government conducted litigation by utilizing the monitoring function at the WTO by voicing objections to the European Union's policy as Specific Trade Concerns (STCs) in various organizations. Mr. Febrian Alphyanto Ruddyards said the same thing as Director-General of the Ministry of Foreign Affairs Multilateral Cooperation quoted from bsn.go.id, which noted that the government of the Republic of Indonesia had taken several steps in the WTO committees to protests the European Union's policy plan. It was implemented the policies Renewable Energy Directive (RED) II, which has the potential to discriminate palm oil through sustainability issues (bsn.go.id, 2018).

On March 20-22, 2018, for the first time, the Indonesian delegation expressed their objections to the development of the RED EU amendment policy related to Indonesian CPO at WTO, Geneva Switzerland (mission-indonesia.org, 2018). In this 
forum, the Indonesian delegation stated that Indonesia already has standard sustainable palm oil, namely ISPO - equivalent to the RSPO - as a form of Indonesia's policy on sustainability. Also, the development of sustainable palm oil and its derivative products play a role in improving the welfare of the people of Indonesia, including supporting the efforts of the Indonesian government to fulfill the commitments of Indonesia's Sustainable Development Goals (SDGs). Therefore, through this forum, Indonesia urges the European Union not to implement discriminatory policies and adjust its commitments to WTO provisions.

The result of the author's interview with Mr. Anwar as the Head of SubDirectorate I of the Directorate for American and European Interregional Cooperation, indeed confirmed that Indonesia had filed a lawsuit with the WTO. According to him, the European Union policy through RED II is an act of discrimination and affects the Indonesian palm oil brand to Europe. This policy will have an impact on the trade sector. He said that the image of Indonesian palm oil was terrible in the minds of the European Union. Indonesia's goal is to want this discrimination to be stopped so that trade between countries can continue to run well.

Environmental diplomacy at the global level through the WTO is expected to be taken seriously by the European Union. It is because Indonesia also has the support of other WTO member countries - they are Malaysia, Thailand, Colombia, Costa Rica, Guatemala, and Nigeria, also voicing concerns similar to Indonesia (missionindonesia.org, 2018). All forms of government policies in the country, both BRG and the palm moratorium, were carried out as a reform of Indonesia and a tool for the government in carrying out Indonesia's environmental diplomacy to the global level.

Environmental diplomacy will succeed if accompanied by instruments that help accelerate diplomacy is successful. In addition to restructuring the environmental conditions in Indonesia, various methods are also being taken to fight the Indonesian black palm oil campaign. Indonesia must be able to move the mass media so that more positive things about the Indonesian palm oil industry. The instrument used by the Ministry of Foreign Affairs, as mentioned by Mr. Dindin Wahyudin, is through a communication strategy. Several communication strategies have been carried out by the Ministry of Foreign Affairs, as follow below :

1. Implementation of RPOPC (Regional Palm Oil Course). The RPOPC is a short course program organized by the Ministry of Foreign Affairs in collaboration with the Oil Palm Plantation Fund Management Agency (BPDKS), Bogor Agricultural Institution, and Jambi University. The program was held on November 26th, 2018. It was followed by consultants, researchers, environmental activists, and academics from 11 countries such as Australia, the Netherlands, the Czech Republic, Hungary, Britain, Italy, France, Poland, Russia, Slovakia, and Spain. RPOPC Participants visited a smallholder oil palm plantation in Jambi to gain a valuable personal view of the sustainable palm oil industry in Indonesia from the farmer's perspective. Participants will be given lectures on policies, facts, and discoveries, the palm oil businesses, or organizational structure in general, and research and development. They also conducted field visits in Jambi Province and oil palm companies that already have ISPO and RSPO certifications. The purpose of this course is that participants are expected to provide correct information about the palm oil industry in Indonesia. This program, as one of the instruments of 
Indonesia's environmental diplomacy, so that the image of oil palm can be changed, especially from the perspective of the European Union.

2. The second communication strategy is through media such as films and advertisements. Palm oil is widely reportedly in negative campaigns, throughs advertising, and news media. Environmental diplomacy must have a strategy in countering the attack by preaching positive palm oil campaigns such as one of them, namely through a documentary about the positive impacts of palm oil. Some palm oil campaign films are now starting to appear. For example, a documentary film titled "Cahaya" tells a story of a child of an oil palm farmer who got a college undergraduate scholarship from the government. This film is a collaboration between the Ministry of Energy and Mineral Resources and BPDP palm oil. The presence of government intervention in filmmaking is a sign that Indonesia has taken into account current environmental diplomacy.

The next film is titled "Human in Oil." This film was initiated by the Ministry of Foreign Affairs by involving the Dutch production house "Docsfair" in its launch. Dutch involvement in filmmaking "Human in Oil" is a strategy for Europeans to know that palm oil has a positive impact on the environment and people's welfare. The Ministry of Foreign Affairs hopes this film can provide a humanist perspective on oil palm products, and it can lead misleading opinions formed by various parties in the European Union, especially those related to the environment.

The Film "Human in Oil" highlights promotes on how palm oil changes the lives of Jambi smallholders and their point of view if European Union countries prohibit palm oil imports. The film, which was launched at the Docsfair International Film Festival in Amsterdam, Netherlands, Friday, November 22nd, 2019, shows how the management of palm oil industry in Indonesia is responsible and environmentally friendly, according to ISPO and RSPO standards. Indonesian Deputy Foreign Minister Mahendra Siregar said at the launch of the film that through this film, it was hoped that Dutch and European people could study, absorb and interpret this issue from a different perspective from the ideologies, opinions, and emotions regarding palm oil. He is also added that we cannot change perceptions overnight, but this film is the first step to build a deep global understanding (bumn.go.id, 2019).

The communication strategy that has been described will be even more effective if environmental diplomacy is carried out by Indonesian representatives as the best practice of Indonesian environmental diplomacy. Environmental diplomacy has become an increasingly central foreign policy instrument in Indonesian diplomacy. Indonesian diplomats are spearheading the success or failure of diplomacy. Several ministries involved themselves in encouraging the success of Indonesia's environmental diplomacy, starting from the Ministry of Foreign Affairs, the Coordinating Ministry for Maritime Affairs and Investment, the Ministry of Energy and Mineral Resources, and Indonesian representative working together to contribute to Indonesia's environmental diplomacy.

The Indonesian delegation in defending Indonesian palm oil was not only from diplomats but also ministers and even the President, negotiating directly with the European Commission to discuss a win-win solution between the two parties. Palm oil has become an important topic, mainly when often addressed in presidential speeches or 
to the Minister. In each meeting between countries, it is not uncommon for Minister to hold bilateral meetings to discuss the issue of palm oil. As on July 3rd, 2018, Indonesia Foreign Minister Retno Marsudirini met with Foreign Minister of the Kingdom of the Netherlands Stef Blok in the Pancasila Building of the Indonesian Ministry of Foreign Affairs (merdeka.com, 2018). In this meeting, the Indonesian Foreign Minister raised the issue of palm oil because the Netherlands is one of the largest export destinations of Indonesian palm oil. Foreign Minister Retno discussed the best solution so that there is no more discrimination against palm oil, especially by using ILUC as a criterion that reflects a more European view than an internationally accepted view.

In several ASEAN high-level meetings, President Joko Widodo, in his speech, always included the issue of Indonesian palm oil. For example, it was at the High-Level Conference (Summit) 40 ${ }^{\text {th }}$ Anniversary of the ASEAN-European Union Partnership Cooperation, which held on November 14th, 2017, at the Philippines International Convention Center (PICC), Manila, Philippines. During the meeting, President Joko Widodo firmly stated discrimination against Indonesian palm oil by the European Union must be stopped immediately. Some attitudes and policies that are considered too damaged economic interests and damage the image of oil-producing countries, which are also members of ASEAN, must be eliminated. The President also added that Indonesia already understands the importance of sustainability. Therefore, Indonesia already has ISPO as a standards certification for sustainable palm oil producing companies (Humas Sekterariat Kabinet Indonesia, 2017).

Although several instruments have been carried out by the government, the European Union still issued their statements as outlined in RED II. After RED II's announcement from the European Commission, the government felt that the European Union has discriminated against Indonesian palm oil. Therefore, as a form of diplomacy, the government lobbied by writing a letter to the WTO and writing down objections to EU actions. The government feels that palm oil as a commodity from Indonesia's natural resources has helped reduce poverty and contribute foreign exchange to the country. Luhut Binsar Panjaitan, as the Coordinating Ministry of Maritime Affairs, said that palm oil contributes to the welfare of the community. Retno Marsudi, also as Minister of Foreign Affairs in his speech, said that diplomacy would be optimized to safeguard the strategic interests of Indonesia's economy. One of them is palm oil which is a diplomatic priority in the leadership of President Joko Widodo's government:

"The importance of Indonesian palm oil is fundamental because it involves the interests of approximately 16 million people, especially small farmers, and their families. We will continue to reject various discriminatory actions aimed at palm oil because it is not only detrimental to the national interests but also threatens to meet the needs of the majority of the world's population for vegetable oils that meet the SDGs criteria" (kemlu.go.id, 2019)

Until now, all efforts have been mobilized by the government to solve the palm oil problem. All instruments are used, such as through media, seminar, lobbies conducted by the Indonesian delegation solely as a form of environmental diplomacy, which is currently undergoing reform in Indonesia. 


\section{Domestic and institutional setting}

The institutional aspect is an analysis of researchers based on the practice of environmental diplomacy by Indonesia regarding the rejection of CPO by the European Union. The institutional point is an insight from the theory of two-level games about strengthening the domestic government before negotiating abroad. Concerning Indonesia's CPO environmental diplomacy, to take the policy, there is a robust institutional element because this problem involves many parties. The authors analyze there is a dominant institutional aspect related to the plan to reject Indonesian palm oil, especially in conducting its diplomacy. Palm oil exports will not be separated from the Ministry of Trade because it is related to international trade.

The problem of the planned rejection of CPO by the European Union is due to the issue of deforestation so that the solution will involve the Indonesian Ministry of Environment and Forestry and the Ministry of Foreign Affairs. KLHK will assist in explaining the land-use change, greenhouse gas emissions, and deforestation. At the same time, the Ministry of Foreign Affairs will assist in the field of environmental diplomacy to the bilateral, regional, and global levels. In addition to these three ministries, the Coordinating Ministry Maritime and Investing also helped in the diplomacy of the palm oil environment to the European Union. These ministries carry out their respective duties by involving palm oil associations such as GAPKI to maintain the existence of Indonesian palm oil exports.

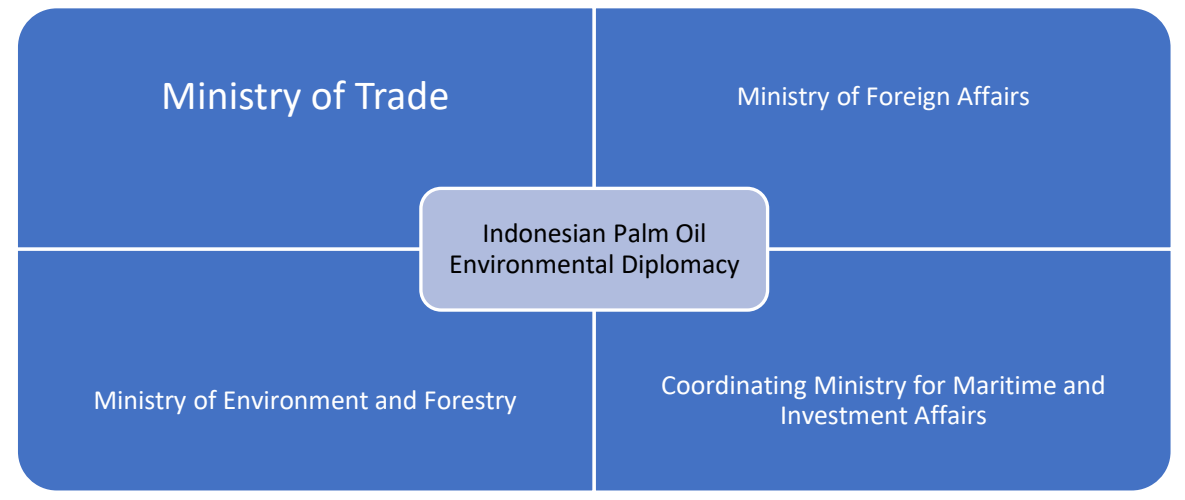

The chart above illustrates the relevant ministries that handle Indonesia's environmental diplomacy in several countries to socialize Indonesia's CPO. The departments listed in the table are the most active in carrying out Indonesia's environmental diplomacy. In the diplomacy carried out, of course, negotiating with the European Union and showing that Indonesia's CPO meets environmental standards.

According to the researcher interview with Mr. Anwar Luqman Hakim, Head of Sub-Directorate I of the Directorate of American and European Interregional Cooperation, he said that coordination with other ministries had been carried out. The President has determined the tasks that must be carried out by the relevant departments through the National Action Plan to conduct environmental diplomacy to the European Union. He said that this was a commitment from the highest level that the Indonesian government had tried to help resolve this issue. He also noted that the stages that had to be done and would be carried out in the future were clearly stated. 
The National Action Plan is the latest policy of President Joko Widodo to increase diplomacy to achieve sustainable palm oil plantations, issued by Presidential Instruction No. 6 of 2019 on the National Action Plan for Sustainable Palm Oil (RAN KSB). The presidential instruction addressed to several ministries (including those written in the chart above). The Presidential Decree clearly stated the duties, functions, and authorities of each to be carried out from 2019 to 2024. The RAN KSB is a form of Indonesia's compliance with international regimes related to sustainable palm oil and as a material for Indonesia's environmental diplomacy to the European Union.

Effective environmental diplomacy requires multi-stakeholder cooperation. It is starting from the top President, ministries, NGOs, entrepreneurs to smallholders in palm oil plantations. Many policies have been carried out by cooperating with several departments to conduct environmental diplomacy. For example, Mr. Anwar said that one form of institutional aspects in environmental diplomacy is that in Indonesia itself, in doing diplomacy plans driven by the Ministry of Cooperatives, those who are the motor and directors of how Indonesia responds to this palm oil issues. It consists of ministries, namely the Ministry of Agriculture, Forestry, KLHK, and the Ministry of Foreign Affairs. The Ministry of Foreign Affairs itself is certainly about its duty to think about diplomacy strategies and also to fight for how the Indonesian Sustainable Palm Oil (ISPO) is becoming a certification standard that is accepted by overseas markets, including the European Union and outside the European Union.

Practical multi-stakeholder cooperation will be critical in the success of environmental diplomacy related to the Indonesian palm oil problem. The relevant ministries are required to carry out a job desk that has been created. Data owned by the Ministry of Foreign Affairs and KLHK, for example, should be the same. It is where the role of institutional aspects to coordinate the parties involved in conducting environmental diplomacy. If there is proper coordination between institutions, then Indonesia has a voice in the international environmental forum.

\section{Conclusion and Recommendation}

Based on research related to Indonesian CPO, which is planned to begin in 2020, will be limited by the European Union, it can be concluded in several things. First, palm oil is not only a strategic commodity for the Indonesian economy but also a commodity that can help achieve sustainable development goals. The product is very supportive in terms of rural development, creating employment opportunities, and restoring the economy of small farmers. These factors are the reason palm oil is in Indonesia's environmental diplomacy. Environmental diplomacy is at the forefront of Indonesia in negotiating with the European Union and restoring the right name of Indonesia palm oil internationally.

In the growth of the palm oil industry, it faces challenges, especially from the European Union. Indonesia believes that the European Union policy is an act of discrimination as evidence by data and research results that have denied the EU's opinion on palm oil. Through this conviction, Indonesia has taken several actions through bilateral, regional, and even global cooperation to resolve this stickiness as best practice in Indonesia's CPO environmental diplomacy.

Second, Indonesia has already fulfilled the environmental sustainability requirements of the international regime. The policy issued by President Joko Widodo during 2014-2019 is Indonesia's effort to contribute to the development of a sustainable 
environment. BRG and the palm moratorium are one of the contents of Indonesia's contribution to producing sustainable palm oil. Also, during his administration, ministries and agencies coordinated so that Indonesia's environmental diplomacy at the international level had one voice.

Third, during the reign of President Joko Widodo, there have been many forms of implementation of environmental diplomacy related to the plan to reject Indonesian palm oil by the European Union. Bilateral cooperation, especially with Malaysia to the global level through the WTO, was carried out during the administration of President Joko Widodo. Various media are also used, namely from the media of films, advertisements, and even state speeches, which always include the issue of palm oil in meetings to achieve a win-win solution in this matter.

The institutional aspect in overcoming the issue of rejection of Indonesian CPO by the European Union is the application of the theory of two-level games relating to environmental diplomacy. In the institutional aspect, there will always be a tug of war between economic interests and the environment. Indonesia must meet two challenges simultaneously. Therefore, good governance in institutional coordination will make diplomacy successful. Through institutional coordination, Indonesia proves that the country is an international actor and is also trying to achieve its own country's development targets.

From these three conclusions, we can draw that Indonesian is in this environmental diplomacy succeeded in linking aspects of population, economic development, and the environment. It is the remain essence of Indonesia's environmental diplomacy. Indonesia strives to continue to follow the international regime's provisions on the environment but does not sacrifice national economic development. 


\section{BIBLIOGRAPHY}

\section{Books}

American Institute for Contemporary German Studies. 1998. Environmental Diplomacy. Washington, DC: The John Hopkins University.

Kate O'Neill. 2009. The Environment and International Relations. Cambridge University Press. Pearson Education Limited: UK

Balaam, N. David, and Bradford Dilman. (2014). Introduction to International Political Economy. Pearson: USA

Burchill, S., 2013. Theories of International Relations. Palgrave Macmillan: USA

Dunne, Tim. 2013. International Relations Theories; Discipline and Diversity. Oxford University Press UK

Jemadu, Alexius. 2017. Politik Global dalam Teori dan Praktik. Suluh Media : Yogyakarta

Krasner, SD (1983). (ed.). International Regimes. Ithaca. NY: Cornell University Press

Cresswell, John. W. 2014. Research Design Qualitative, Quantitative, and Mixed Methods Approaches. Sage Publications: USA

Neuman, W. Lawrence. 2014. Social Research Methods Qualitative and Quantitative Approaches. Pearson Education Limited UK

Pramudianto, Andreas. 2018. Diplomasi Lingkungan : Teori dan Fakta. Jakarta : UI Press

SpringerAllen. 2002. International Environmental Cooperation Politics and Diplomacy in Pacific Asia. University Press of Colorado USA.

\section{Journals}

Alam, A.S.A Ferdous, A.C era, nd Halima Begum. (2015). Malaysian Oil Palm Industry: Prospect and Problem. Journal of Food, Agriculture \& Environment Vol.13 (2):143-148

Cattau, Megan E, Miriam E Marlier, and Ruth DeFries. 2016. Effectiveness of Roundtable on Sustainable Palm Oil. (RSPO) for Reducing Fires on Oil Palm Concessions in Indonesia from 2012 to 2015. Environmental Research Letters 1-11

Glastra, Rob, Eric Wakker, and Wolfgang Richert. 2002. Oil Palm Plantations and Deforestation in Indonesia: What Role do Europe and Germany Play? Dreierich: WWF Schweiz.

Köhne, Michiel. 2014. Multi-stakeholder Initiative Governance as Assemblage: Roundtable Sustainable Palm Oil as a Political Resource in Land Conflicts related to Oil Palm Plantation. Agriculture Humanity 469-480.

Lawrence E. Susskind. 1994. Environmental Diplomacy: Negotiating More Effective Global Agreements. Oxford University Press: New York.

Mcbeath, Jerry, and Bo Wang. 2008. China's Environmental Diplomacy. American Journal of Chinese Studies Vol.15, No.1, pp.1-16

Nikoluyuk, Jordan, Tom Burns, and Reinier de Man. 2010. The Promise and limitations of Partnered Governance: The Case of Sustainable Palm Oil. Corporate Governance 59-72.

Pamela S. Chasek. 2001. Earth Negotiations: Analyzing thirty years of environmental diplomacy. United Nations University Press: USA 
Pisupati, Balakrishna. 2015. South-South Cooperation and Environmental Diplomacy. Forum Paper for Law, Environment, Development, and Governance (FLEDGE). India pp: 17

Putnam, Robert D., 1988. Diplomacy and Domestic Politics: The Logic of Two-Level Games. International Organization Vol.42, No.3, pp. 427-460.

Saleem H. Ali. 2016. Environmental Diplomacy. The Sage Handbook of Diplomacy

Sinaga, Obsatar. 2018. The Crisis of Pluralism in Environmental Studies of English School? Case Study of Joko Widodo's Environmental Diplomacy (2014-2019). The Turkish Online Journal of Design, Art, and Communication - TOJDAC. p.15971608

Robertua, Verdinand. 2018. The Deconstruction and Reconstruction of Global Environmental Governance: Case Study of Peat Restoration Agency. Jurnal AsiaPacific Studies Vol. 2 Number 2. pp. 180-196

Santosa, MA dan Januar, DP, 2016. Enhancement of Forest and Peatland Governance in Indonesia. Indonesia Journal of International Law, 13, 344-352.

Varkkey, Helena Muhammad. 2011. Addressing Transboundary Haze Through ASEAN: Singapore's Normative Constraints. Journal of International Studies 7, 83-101

Yani, Mochamad Yanyan, and Robertua, Verdinand. 2018. Environmental Studies of English School: Case Study of Forest Fires in Indonesia and Transboundary Haze in Southeast Asia. Journal of ASEAN Studies, Vol.6, No.1 (2018), pp.117-135

\section{Interview}

Kementerian Pertanian RI. 2015. Statistik Perkebunan Kelapa sawit Indonesia 20142016. Kementerian Pertanian RI : Jakarta

PASPI (Palm Oil Agribusiness Strategic Policy Insititute). 2015. Labelisasi Produk "Palm Oil Free": Gerakan Boikot Minyak Sawit ?. Vol. I No.15 / 25. www.paspi.web.id

\section{Internet}

Julianto, Pramdia Arhando. 2018. Kementan: Industri Kelapa Sawit Berkontribusi Besar terhadap Ekonomi. Maret 2019. Diakses Maret 9, 2019. https://www.ekonomi.kompas.com

Embassy of The Republic of Indonesia in Brussels, Belgium. 27 Maret 2019. Indonesia Reiterated the "Win-Win Solution Related to Oil Palm to the European Union". Diakses January 12th, 2020. https://kemlu.go.id/brussels/en/news/451/indonesiareiterated-the-win-win-solution-related-to-oil-palm-to-the-european-union\#

Sekretariat Kabinet Indonesia. 25 Januari 2014. Bertemu Presiden Uni Eropa, Jokowi Minta Dibantu Masuknya Kelapa Sawit Indonesia ke Eropa. Diakses 10 Maret 2019. https://setkab.go.id/bertemu-presiden-uni-eropa-jokowi-minta-dibantumasuknya-kelapa-sawit-indonesia-ke-eropa.

Sekretariat Kabinet Indonesia. 14 November 2017. Hadiri KTT ASEAN-Uni Eropa, Presiden Jokowi Minta Diskriminasi Kelapa Sawit Dihentikan. Diakses 12 Januari 2020. https://setkab.go.id/hadiri-ktt-asean-uni-eropa-presiden-jokowi-mintadiskriminasi-kelapa-sawit-dihentikan/

Sekretariat Kabinet Indonesia. 28 November 2019. Terima Dewan Bisnis Uni EropaASEAN, Presiden Jokowi Kritik Diskiriminasi Kelapa Sawit Indonesia. 
https://setkab.go.id/terima-dewan-bisnis-uni-eropa-asean-presiden-jokowi-kritikdiskriminasi-kelapa-sawit-indonesia_trashed/

Surya Perkasa. 2015. Ekspansi Kelapa Sawit Indonesia. https://m.medcom.id/telusur/medcom-files/zNP5v4Wb-ekspansi-kelapa-sawit-diindonesia. Diakses 13 Februari 2020

Supriyono, Joko. 2018. Sejarah Kelapa Sawit Indonesia. https://gapki.id/news/3652/video-sejarah-kelapa-sawit-indonesia. Diakses 14 Februari 2020.

CPOPC. 2019. https://www.cpopc.org/news/ways-forward-for-palm-oil-producingcountries/. Diakses 2 Desember 2019

Farah Fuadona. 2018. https://www.merdeka.com/dunia/bertemu-menlu-belanda-menluretno-bahas-diskriminasi-kelapa-sawit.html. Diakses 5 Desember 2019.

Luhut Kirim Tim Perumus Kriteria Impor Sawit ke Uni Eropa. 2018. https://www.cnnindonesia.com/ekonomi/20180626084701-92-309041/luhutkirim-tim-perumus-kriteria-impor-sawit-ke-uni-eropa?. Diakses 4 Desember 2019.

Badan Standardisasi Nasional. 2018. https://bsn.go.id/main/berita/detail/9824/indonesiaperjuangkan-perdagangan-kelapa-sawit-di-dunia-internasional. Diakses 2 Desember 2019

Film Human in Oil Lawan Opini Sesat Soal Sawit. 2019. http://bumn.go.id/ptpn5/berita/kategori/1. Diakses 4 Desember 2019.

UNFCCC. 2015. Statement of the President of the Republic of Indonesia. http://unfecc.int/files/

meetings/paris_nov_2015/application/pdf/cop21cmp11_leaders_event_indonesia. pdf 